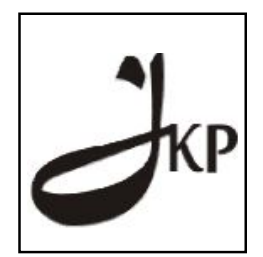

Info Artikel:

Diterima 06/06//2015

Direvisi 12/06/2015

Dipublikasikan 30/06/2015
Jurnal Konseling dan Pendidikan

ISSN Cetak: 2337-6740 - ISSN Online: 2337-6880

http://jurnal.konselingindonesia.com

Volume 3 Nomor 2, juni 2015, HIm 40-48

\title{
Efektivitas Layanan Informasi dengan Menggunakan Media Audio Visual dalam Meningkatkan Sikap Siswa terhadap Kedisiplinan Sekolah
}

Nory Natalia, Firman \& Daharnis

Universitas Negeri Padang

Abstract

The research based on phenomenon where students has low attitude in school discipline, such as many students who break the rules in their the absence, the uniform and learning activity, where it can be effect on learning quality and quantity. Guidance and counseling is to improve student's attitude on school discipline, one of them is information services. The research purpose to test effectiveness of information services with using the audio visual media to improve students attitude on school discipline. This research use quantitative method. Type of this research is Quasi Experiment with Non Equivalent Control Group Design. The population are students at SMP Muhammadiyah Padang Panjang and sample selected with using purposive sampling. The instrument is questionnaire with Likert Scale and tested for validity and reliability. The validity test used Product Moment Correlation with mean correlation coefficient 0.642 and the reliability test used Cronbach's Alpha with r 0.965. Then analysis technique using Wilcoxon Signed Ranks Test and Kolmogorov Smirnov 2 Samples Independent using SPSS 20. The results showed that information service with using the audio visual media effective to improve students attitude on school discipline.

Keyword: Students Attitude, School Discipline, Information Services.

Copyright (C) 2015 IICE - Multikarya Kons (Padang - Indonesia) dan IKI - Ikatan Konselor Indonesia - All Rights Reserved Indonesian Institute for Counseling and Education (IICE) Multikarya Kons

\section{PENDAHULUAN}

Pendidikan merupakan salah satu aspek utama dalam membangun suatu bangsa. Di sisi lain, pendidikan juga merupakan sarana dalam menjadikan individu berkualitas, cerdas dan bermoral. Melalui pendidikan setiap individu dapat mengembangkan potensi-potensi yang dimiliki serta dapat memperoleh keterampilan-keterampilan baru yang bermanfaat bagi kehidupannya.

Proses membentuk siswa yang berkualitas, berprestasi dan sukses ditopang oleh banyak hal, seperti IQ yang dimiliki, ketekunan, kebiasaan yang baik dan kedisiplinan. Kedisiplinan sebagai salah satu penopang hal tersebut, berperan sebagai suatu kekuatan positif yang berkontribusi dalam kehidupan sehari-hari sebagai suatu alat atau piranti agar siswa dapat mengatur dan mengontrol segala rutinitasnya sehari-hari baik di lingkungan keluarga, sekolah dan masyarakat. Pada hakikatnya, disiplin bukan hanya merupakan kepatuhan pada norma yang dipaksakan dari luar, melainkan kemampuan mengendalikan diri yang didasarkan pada keinginan untuk menciptakan keteraturan dan ketertiban di dalam kehidupan (Durkheim, 1990:100).

Pada lembaga pendidikan disiplin memiliki arti yang sangat penting bagi siswa, karena dengan adanya sikap siswa terhadap kedisiplinan sekolah akan tercipta suasana yang kondusif saat proses belajar dan pembelajaran di sekolah. Dengan adanya situasi yang kondusif, siswa akan dapat berkonsentrasi dalam belajar, yang akhirnya berdampak pada hasil belajar yang meningkat. Sebaliknya, apabila pada suatu sekolah rendah sikap siswa terhadap kedisiplinan sekolah tentu akan berpengaruh pada proses belajar dan pembelajaran, dimana dapat menimbulkan ketidakdisiplinan yang pada akhirnya akan berdampak pada menurunnya mutu dan hasil belajar siswa. 
SMP Muhammadiyah Padang Panjang sebagai lokasi penelitian dipilih karena merupakan salah satu sekolah swasta di Padang Panjang yang memiliki tingkat kedisiplinan sekolah yang rendah. Hal ini berdasarkan data dari buku pelanggaran yang dimiliki setiap siswa di sekolah dan data dari buku guru piket pada awal semester 1 tahun ajaran 2014-2015, seperti: (1) masih banyaknya siswa yang datang terlambat setiap hari ke sekolah, (2) siswa yang tidak memakai seragam sekolah sesuai dengan hari yang ditentukan, (3) siswa yang tidak lengkap memakai atribut sekolah pada seragamnya, (4) banyak potongan rambut siswa laki-laki yang tidak sesuai dengan standar potongan rambut seorang pelajar, (5) memakai sepatu selain warna hitam, (6) saat pergantian jam pelajaran, banyak siswa yang berkeliaran di luar kelas, (7) siswa yang membawa handphone dan komik ke sekolah, (8) masih ada siswa yang bolos saat jam pelajaran berlangsung dan (9) masih terdapat siswa yang tidak masuk sekolah tanpa ada keterangan.

Dewa Ketut Sukardi (2003:42) menjelaskan bimbingan dan konseling merupakan salah satu bagian terpenting dari sebuah pendidikan yang memiliki tiga fungsi yaitu pemahaman, pencegahan dan perbaikan. Dari ketiga fungsi tersebut bimbingan dan konseling dipandang memiliki peran dan kontribusi dalam memberikan pemahaman serta mengembangkan perilaku kedisiplinan pada diri setiap siswa sehingga dapat menjalani kehidupan sehari-hari yang efektif dan siswa mampu melaksanakan semua aktivitasnya dengan teratur dan berkualitas. Salah satu layanan dalam bimbingan dan konseling yang tepat diberikan kepada siswa agar dapat meningkatkan perilaku kedisiplinan siswa di sekolah adalah layanan informasi.

Perilaku ketidakdisiplinan yang timbul disebabkan oleh sikap yang dimiliki oleh setiap siswa (Green, dalam Soekidjo Notoadmojo, 1993:116). Pada dasarnya sikap yang dimiliki oleh setiap siswa sudah ada, akan tetapi sikap tersebut masih lemah sehingga antara sikap dan perilaku yang timbul tidak konsisten (Taylor, Peplau \& Sears, 2012:199). Berdasarkan hal tersebut, untuk meningkatkan sikap terhadap kedisiplinan sekolah dapat dilakukan dengan pemberian informasi pada setiap siswa (Krech, Crutchfield \& Ballachey, 1962:180).

Pelaksanaan layanan informasi telah dilakukan oleh guru BK atau konselor, akan tetapi layanan informasi yang dilaksanakan belum optimal. Hal ini mengakibatkan urgensi dari isi layanan informasi tentang kedisiplinan kurang sampai kepada siswa yang akhirnya sikap siswa terhadap kedisiplinan sekolah masih lemah. Oleh karena itu, pelaksanaan layanan informasi dapat dioptimalkan dan diaktifkan dengan menggunakan media tambahan dan metode (Tohirin, 2007:152). Salah satu media yang dapat dipergunakan sebagai media tambahan atau pendukung dalam pelaksanaan layanan informasi adalah media audio visual. Berdasarkan hal tersebut, perlu diteliti layanan informasi yang lebih kreatif untuk meningkatkan sikap siswa terhadap kedisiplinan sekolah yaitu layanan informasi dengan menggunakan audio visual.

Penelitian ini secara umum bertujuan untuk menguji efektivitas layanan informasi dengan menggunakan media audio visual dalam meningkatkan sikap siswa terhadap kedisiplinan sekolah. Sedangkan tujuan khusus untuk menguji: (1) perbedaan sikap siswa kelompok eksperimen terhadap kedisiplinan sekolah sebelum dan sesudah mengikuti layanan informasi dengan media audio visual, (2) perbedaan sikap siswa kelompok kontrol terhadap kedisiplinan sekolah sebelum dan sesudah mengikuti layanan informasi tanpa media audio visual dan (3) perbedaan sikap siswa kelompok eksperimen yang diberikan layanan informasi dengan media audio visual dan kelompok kontrol yang diberikan layanan informasi tanpa media audio visual terhadap kedisiplinan sekolah.

\section{METODE PENELITIAN}

Penelitian ini termasuk dalam Quasi Experiment dengan desain The Non Equivalent Control Group. Populasi dalam penelitian ini adalah siswa SMP Muhammadiyah Padang Panjang. Sampel adalah siswa kelas VIII A dan siswa kelas VIII B berjumlah 50 orang yang dipilih dengan menggunakan teknik purposive sampling. Instrumen yang digunakan berupa angket dengan model Skala Likert. Uji validitas instrumen penelitian melalui uji validitas isi oleh beberapa ahli dan juga dilakukan menggunakan Product Moment Correlation dengan mean koefisien korelasi 0.642 dan uji reliabilitas menggunakan rumus Alpha Cronbach dengan r 0.965.

Data yang terkumpul dianalisis dengan cara menghitung skor rata-rata sikap siswa terhadap kedisiplinan sekolah. Setelah deskripsi data tersebut, dihitung rentangan data atau interval. Agus Irianto (2010:22) menjelaskan untuk menghitung rentangan data atau interval dapat dilakukan dengan menghitung data tertinggi dikurang data terendah lalu dibagi jumlah kelas, sehingga diperoleh kategori yang diklasifikasikan dengan kriteria pada tabel berikut. 
Tabel 1. Kategorisasi Sikap Siswa terhadap Kedisiplinan Sekolah

\begin{tabular}{|c|c|}
\hline Skor & Kategori \\
\hline$\geq 252$ & Sangat Positif \\
\hline $204-251$ & Positif \\
\hline $156-203$ & Cukup Positif \\
\hline $108-155$ & Tidak Positif \\
\hline$\leq 107$ & Sangat Tidak Positif \\
\hline
\end{tabular}

Selanjutnya data yang diperoleh dianalisis dengan menggunakan uji Wilcoxon Signed Ranks Test dan Kolmogorov Smirnov 2 Independent Samples.

\section{HASIL DAN PEMBAHASAN}

1. Hasil

a. Sikap Siswa Kelompok Eksperimen terhadap Kedisiplinan Sekolah

Data penelitian yang diperoleh pada kelompok eksperimen sebelum dan sesudah diberikan perlakuan terdapat pada tabel dan gambar berikut.

Tabel 2. Perbandingan Sikap Siswa Kelompok Eksperimen pretest-posttest terhadap Kedisiplinan Sekolah

\begin{tabular}{|c|c|c|c|c|}
\hline \multirow{2}{*}{ Kode } & \multicolumn{2}{|c|}{ Pretest } & \multicolumn{2}{c|}{ Posttest } \\
\cline { 2 - 5 } Siswa & Skor & Kategori & Skor & Kategori \\
\hline E 1 & 207 & P & 253 & SP \\
\hline E 2 & 190 & CP & 229 & P \\
\hline E 3 & 203 & CP & 234 & P \\
\hline E 4 & 196 & CP & 231 & P \\
\hline E 5 & 195 & CP & 236 & P \\
\hline E 6 & 138 & TP & 190 & CP \\
\hline E 7 & 152 & TP & 207 & P \\
\hline E 8 & 133 & TP & 185 & CP \\
\hline E 9 & 148 & TP & 206 & P \\
\hline E 10 & 141 & TP & 211 & P \\
\hline E 11 & 151 & TP & 206 & P \\
\hline E 12 & 140 & TP & 207 & P \\
\hline E 13 & 143 & TP & 212 & P \\
\hline E 14 & 145 & TP & 215 & P \\
\hline E 15 & 146 & TP & 206 & P \\
\hline E 16 & 146 & TP & 205 & P \\
\hline E 17 & 148 & TP & 214 & P \\
\hline E 18 & 151 & TP & 207 & P \\
\hline E 19 & 149 & TP & 205 & P \\
\hline E 20 & 144 & TP & 206 & P \\
\hline E 21 & 148 & TP & 212 & P \\
\hline E 22 & 145 & TP & 217 & P \\
\hline E 23 & 107 & STP & 160 & CP \\
\hline E 24 & 105 & STP & 165 & CP \\
\hline E 25 & 104 & STP & 162 & CP \\
\hline Rata-rata & $\mathbf{1 5 1}$ & TP & $\mathbf{2 0 7 , 2 4}$ & P \\
\hline Keterang & & & & \\
\hline
\end{tabular}

Keterangan.

SP : Sangat Positif

$\mathrm{P} \quad$ : Positif

CP : Cukup Positif

TP : Tidak Positif

STP : Sangat Tidak Positif 
Gambar 1. Hasil Pretest dan Posttest Sikap Siswa Kelompok Eksperimen terhadap Kedisiplinan Sekolah

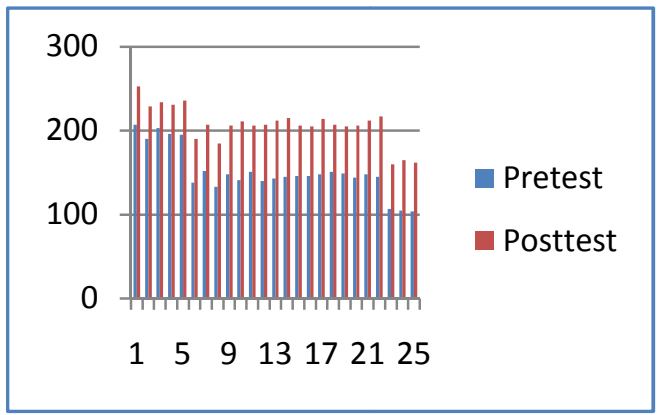

Berdasarkan tabel dan gambar di atas terlihat bahwa sikap siswa kelompok eksperimen terhadap kedisiplinan sekolah meningkat secara signifikan sesudah diberikan perlakuan layanan informasi dengan media audio visual.

b. Sikap Siswa Kelompok Kontrol terhadap Kedisiplinan Sekolah

Data penelitian yang diperoleh pada kelompok kontrol sebelum dan sesudah diberikan perlakuan terdapat pada tabel dan gambar berikut.

Tabel 3. Perbandingan Sikap Siswa Kelompok Kontrol pretest-posttest terhadap Kedisiplinan Sekolah

\begin{tabular}{|c|c|c|c|c|}
\hline \multirow{2}{*}{$\begin{array}{l}\text { Kode } \\
\text { Siswa }\end{array}$} & \multicolumn{2}{|c|}{ Pretest } & \multicolumn{2}{|c|}{ Posttest } \\
\hline & Skor & Kategori & Skor & Kategori \\
\hline K 1 & 207 & $\mathrm{P}$ & 230 & $\mathrm{P}$ \\
\hline K 2 & 195 & CP & 215 & $P$ \\
\hline K 3 & 186 & $\mathrm{CP}$ & 203 & $\mathrm{CP}$ \\
\hline K 4 & 193 & $\mathrm{CP}$ & 204 & $\mathrm{P}$ \\
\hline K 5 & 198 & $\mathrm{CP}$ & 225 & $P$ \\
\hline K 6 & 147 & TP & 166 & $\mathrm{CP}$ \\
\hline K 7 & 149 & $\mathrm{TP}$ & 169 & $\mathrm{CP}$ \\
\hline K 8 & 139 & $\mathrm{TP}$ & 157 & $\mathrm{CP}$ \\
\hline K 9 & 137 & TP & 149 & TP \\
\hline K 10 & 154 & TP & 170 & $\mathrm{CP}$ \\
\hline K 11 & 150 & $\mathrm{TP}$ & 150 & $\mathrm{TP}$ \\
\hline K 12 & 152 & $\mathrm{TP}$ & 158 & $\mathrm{CP}$ \\
\hline K 13 & 148 & $\mathrm{TP}$ & 166 & $\mathrm{CP}$ \\
\hline K 14 & 146 & $\mathrm{TP}$ & 165 & $\mathrm{CP}$ \\
\hline K 15 & 150 & $\mathrm{TP}$ & 171 & $\mathrm{CP}$ \\
\hline K 16 & 134 & TP & 157 & $\mathrm{CP}$ \\
\hline K 17 & 138 & TP & 150 & TP \\
\hline K 18 & 136 & $\mathrm{TP}$ & 155 & TP \\
\hline K 19 & 145 & $\mathrm{TP}$ & 165 & $\mathrm{CP}$ \\
\hline K 20 & 142 & TP & 156 & CP \\
\hline K 21 & 142 & TP & 155 & TP \\
\hline K 22 & 143 & $\mathrm{TP}$ & 163 & $\mathrm{CP}$ \\
\hline K 23 & 130 & $\mathrm{TP}$ & 145 & $\mathrm{TP}$ \\
\hline K 24 & 107 & STP & 125 & $\mathrm{TP}$ \\
\hline K 25 & 101 & STP & 115 & $\mathrm{TP}$ \\
\hline Rata-rata & 150,76 & TP & 167,36 & $\mathbf{C P}$ \\
\hline
\end{tabular}

SP : Sangat Positif

$\mathrm{P} \quad$ : Positif

CP : Cukup Positif

TP : Tidak Positif

STP : Sangat Tidak Positif 
Gambar 2. Hasil Pretest dan Posttest Sikap Siswa Kelompok Kontrol terhadap Kedisiplinan Sekolah

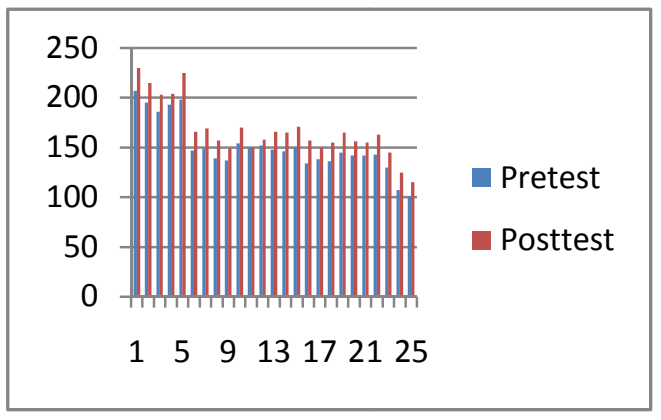

Berdasarkan tabel dan gambar di atas terlihat bahwa sikap siswa kelompok kontrol terhadap kedisiplinan sekolah meningkat sesudah diberikan perlakuan layanan informasi tanpa media audio visual.

c. Sikap Siswa Kelompok Eksperimen yang Diberikan Layanan Informasi dengan Media Audio Visual dan Kelompok Kontrol yang Diberikan Layanan Informasi tanpa Media Audio Visual terhadap Kedisiplinan sekolah

Data penelitian yang diperoleh pada kelompok eksperimen dan kelompok kontrol sesudah diberikan perlakuan terdapat pada tabel berikut.

Tabel 4. Perbandingan Sikap Siswa Kelompok Eksperimen dan Kelompok Kontrol Sesudah Diberikan

\begin{tabular}{|c|c|c|c|c|c|}
\hline \multicolumn{3}{|c|}{ Kelompok Eksperimen } & \multicolumn{3}{|c|}{ Kelompok Kontrol } \\
\hline $\begin{array}{l}\text { Kode } \\
\text { Siswa }\end{array}$ & Skor & Kategori & $\begin{array}{l}\text { Kode } \\
\text { Siswa }\end{array}$ & Skor & Kategori \\
\hline E 1 & 253 & $\mathrm{SP}$ & K 1 & 230 & $\mathrm{P}$ \\
\hline E 2 & 229 & $\mathrm{P}$ & K 2 & 215 & $\mathrm{P}$ \\
\hline E 3 & 234 & $\mathrm{P}$ & $\mathbf{K} 3$ & 203 & $\mathrm{CP}$ \\
\hline E 4 & 231 & $\mathrm{P}$ & K 4 & 204 & $\mathrm{P}$ \\
\hline E 5 & 236 & $\mathrm{P}$ & K 5 & 225 & $\mathrm{P}$ \\
\hline E 6 & 190 & $\mathrm{CP}$ & K 6 & 166 & $\mathrm{CP}$ \\
\hline E 7 & 207 & $\mathrm{P}$ & K 7 & 169 & $\mathrm{CP}$ \\
\hline E 8 & 185 & $\mathrm{CP}$ & K 8 & 157 & $\mathrm{CP}$ \\
\hline E 9 & 206 & $\mathrm{P}$ & K 9 & 149 & $\mathrm{TP}$ \\
\hline E 10 & 211 & $\mathrm{P}$ & K 10 & 170 & $\mathrm{CP}$ \\
\hline E 11 & 206 & $\mathrm{P}$ & K 11 & 150 & TP \\
\hline E 12 & 207 & $\mathrm{P}$ & K 12 & 158 & $\mathrm{CP}$ \\
\hline E 13 & 212 & $\mathrm{P}$ & K 13 & 166 & $\mathrm{CP}$ \\
\hline E 14 & 215 & $\mathrm{P}$ & K 14 & 165 & $\mathrm{CP}$ \\
\hline E 15 & 206 & $\mathrm{P}$ & K 15 & 171 & $\mathrm{CP}$ \\
\hline E 16 & 205 & $\mathrm{P}$ & K 16 & 157 & $\mathrm{CP}$ \\
\hline E 17 & 214 & $\mathrm{P}$ & K 17 & 150 & $\mathrm{TP}$ \\
\hline E 18 & 207 & $\mathrm{P}$ & K 18 & 155 & TP \\
\hline E 19 & 205 & $\mathrm{P}$ & K 19 & 165 & $\mathrm{CP}$ \\
\hline E 20 & 206 & $\mathrm{P}$ & K 20 & 156 & $\mathrm{CP}$ \\
\hline E 21 & 212 & $\mathrm{P}$ & K 21 & 155 & TP \\
\hline E 22 & 217 & $\mathrm{P}$ & K 22 & 163 & $\mathrm{CP}$ \\
\hline E 23 & 160 & $\mathrm{CP}$ & K 23 & 145 & TP \\
\hline E 24 & 165 & $\mathrm{CP}$ & K 24 & 125 & TP \\
\hline E 25 & 162 & $\mathrm{CP}$ & K 25 & 115 & TP \\
\hline $\begin{array}{l}\text { Rata- } \\
\text { rata }\end{array}$ & 207,24 & $\mathbf{P}$ & $\begin{array}{l}\text { Rata- } \\
\text { rata }\end{array}$ & 167,36 & CP \\
\hline
\end{tabular}

Keterangan.

SP : Sangat Positif

$\mathrm{P} \quad$ : Positif

CP : Cukup Positif

TP : Tidak Positif

STP : Sangat Tidak Positif 
Berdasarkan tabel di atas terlihat bahwa sikap siswa kelompok eksperimen yang diberikan layanan informasi dengan media audio visual dan kelompok kontrol yang diberikan layanan informasi tanpa media audio visual terdapat perbedaan.

\section{Pembahasan}

1) Perbedaan Sikap Siswa Kelompok Eksperimen (Pretest dan Posttest) terhadap Kedisiplinan Sekolah

Berdasarkan hasil pengujian hipotesis pertama yang berbunyi "terdapat perbedaan yang signifikan sikap siswa kelompok eksperimen terhadap kedisiplinan sekolah sebelum dan sesudah mengikuti layanan informasi dengan media audio visual". Pengujian dilakukan dengan uji Wilcoxon Signed Ranks Test.

Hasil penelitian yang diperoleh menunjukkan bahwa skor sikap siswa terhadap kedisiplinan sekolah kelompok eksperimen sebelum diberikan perlakukan berbeda dengan sikap siswa terhadap kedisiplinan sekolah sesudah diberikan perlakuan. Skor total sikap siswa terhadap kedisiplinan sekolah sebelum diberikan layananan informasi dengan media audio visual adalah sebesar 3775 dengan nilai mean sebesar 151. Selain itu secara rata-rata skor sikap siswa terhadap kedisiplinan sekolah pada saat pretest berada pada kategori tidak positif.

Sesudah siswa diberikan layanan informasi dengan media audio visual, kondisi sikap siswa terhadap kedisiplinan sekolah mengalami peningkatan yang signifikan. Perolehan skor total posttest kelompok eksperimen adalah sebesar 5181, dengan nilai mean sebesar 207,24 dan siswa berada pada kategori positif. Selisih skor nilai mean sebelum dan sesudah diberikan perlakuan adalah sebesar 56,24.

Perbedaan perolehan skor sikap siswa terhadap kedisiplinan sekolah tersebut adalah akibat diberikan layanan informasi dengan media audio visual. Melalui layanan informasi setiap siswa memperoleh informasi yang diperlukannya, setiap informasi yang didapat akan diolah dan digunakan untuk kepentingan hidup dan perkembangannya, selain mendapatkan pemahaman dari informasi tersebut, siswa juga dapat tercegah dari hal-hal yang tidak baik.

Layanan informasi adalah salah satu jenis layanan dalam bimbingan dan konseling yang berfungsi mengembangkan diri siswa berkenaan dengan sikap dan kebiasaan belajar serta dengan format layanan informasi berupa klasikal memungkinkan banyak siswa dapat memperoleh layanan ini. Dalam pelaksanaan layanan informasi juga dapat dioptimalkan dan juga diaktifkan dengan menggunakan media tambahan dan metode (Tohirin, 2007:152).

Kedisiplinan sekolah adalah objek dari sikap dalam penelitian ini, sikap siswa terhadap kedisiplinan sekolah yang dimaksudkan dalam penelitian ini berhubungan dengan keyakinan akan kedisiplinan sekolah, sikap tersebut adalah kecenderungan akan bertingkah laku untuk mengikuti kedisiplinan sekolah tersebut, sebagai reaksi sikap itu berhubungan dengan dua hal yaitu "like" atau "dislike" (senang atau tidak senang, suka atau tidak suka). Apabila seseorang memiliki sikap senang atau suka akan peraturan tentu akan disiplin dan mematuhi semua bentuk peraturan, akan tetapi sebaliknya apabila tidak suka akan terjadi pelanggaran kedisiplinan sekolah. Sikap dapat konsisten dengan perilaku yang tampak, hal ini disebabkan sikap yang dimiliki kuat, akan tetapi apabila sikap yang dimiliki tersebut lemah atau ambivalen maka akan timbul inkonsistensi antara sikap dan perilaku (Taylor dkk, 2012:199). Salah satu cara untuk meningkatkan sikap siswa terhadap kedisiplinan sekolah dapat dilakukan dengan pemberian informasi kepada siswa (Krech dkk, 1962:180).

Pada kelompok eksperimen, pelaksanaan layanan informasi dengan menggunakan media audio visual mampu meningkatkan sikap siswa terhadap kedisiplinan sekolah. Penerapan media audio visual bermanfaat bagi siswa karena dengan pemberian media audio visual dalam layanan informasi dapat menumbuhkan perubahan yang signifikan pada sikap siswa, membawa kesegaran dan variasi bagi pengalaman belajar siswa, membuat hasil belajar lebih bermakna bagi berbagai kemampuan siswa, mendorong siswa lebih aktif dan terlibat dalam proses pembelajaran serta dapat melibatkan imajinasinya dan memberikan umpan balik yang diperlukan untuk membantu siswa menemukan seberapa banyak materi yang telah mereka pelajari (Dale, dalam Azhar Arsyad, 2007:23).

Berdasarkan penjelasan di atas, pemberian layanan informasi dengan menggunakan media audio visual efektif meningkatkan sikap siswa terhadap kedisiplinan sekolah. 
2) Perbedaan Sikap Siswa Kelompok Kontrol (Pretest dan Posttest) terhadap Kedisiplinan Sekolah

Berdasarkan hasil pengujian hipotesis kedua yang berbunyi "terdapat perbedaan antara sikap siswa kelompok kontrol terhadap kedisiplinan sekolah sebelum dan sesudah mengikuti layanan informasi tanpa media audio visual". Pengujian dilakukan dengan uji Wilcoxon Signed Ranks Test.

Hasil penelitian yang diperoleh menunjukkan bahwa skor sikap siswa terhadap kedisiplinan sekolah kelompok kontrol sebelum diberikan perlakukan berbeda dengan sikap siswa terhadap kedisiplinan sekolah sesudah diberikan perlakuan. Skor total sikap siswa terhadap kedisiplinan sekolah sebelum diberikan layananan informasi tanpa media audio visual adalah sebesar 3769 dengan nilai mean sebesar 150,76 dan siswa berada pada kategori tidak positif. Sesudah siswa diberikan layanan informasi tanpa media audio visual, kondisi sikap siswa terhadap kedisiplinan sekolah juga mengalami peningkatan. Perolehan skor total posttest kelompok kontrol adalah sebesar 4184, dengan nilai mean sebesar 167,36 dan siswa berada pada kategori cukup positif.

Peningkatan sikap siswa terhadap kedisiplinan sekolah yang terjadi pada kelompok kontrol yang hanya mencapai kategori cukup positif disebabkan dengan suasana belajar kelompok kontrol yang kurang adanya variasi. Hal ini menimbulkan kejemuan atau membosankan pada siswa dan akan mudah menimbulkan keletihan. Jika kondisi ini terjadi, maka siswa akan mengalami kejenuhan belajar. Pada saat seperti ini, siswa mengalami penurunan daya ingat dan tidak mampu lagi mengakomodasikan informasi atau pengalaman baru (Fanani, dalam Novasari Mardiana, 2014:23). Walaupun demikian, kelompok kontrol tetap mengalami peningkatkan akan tetapi peningkatan tersebut lebih besar kelompok eksperimen karena layanan informasi pada kelompok kontrol hanya diberikan dengan metode ceramah saja tanpa media audio visual, akhirnya membuat suasana belajar monoton dan pada umumnya siswa hanya menerima apa yang disampaikan oleh guru. Dengan kata lain siswa kurang aktif dalam berpikir dan mengeluarkan pendapat, sehingga urgensi materi dari layanan tersebut kurang sampai kepada siswa.

3) Perbedaan Sikap Siswa terhadap Kedisiplinan Sekolah pada Kelompok Eksperimen dan Kelompok Kontrol

Hasil uji perbedaan sikap siswa terhadap kedisiplinan sekolah pada kelompok eksperimen dan kelompok kontrol menunjukkan terdapat perbedaan, yaitu pada kelompok eksperimen yang diberikan layanan informasi dengan media audio visual dan pada kelompok kontrol yang diberikan layanan informasi tanpa media audio visual.

Uji hipotesis yang telah dilakukan membuktikan bahwa nilai Asymp. Sig. (2-tailed) 0,000<0,05. Dengan demikian dapat disimpulkan bahwa terdapat perbedaan yang signifikan sikap siswa terhadap kedisiplinan sekolah kelompok eksperimen dan kelompok kontrol. Kedua kelompok penelitian diberikan layanan yang sama yaitu layanan informasi, tetapi yang membedakan adalah kelompok eksperimen diberikan media audio visual sedangkan kelompok kontrol tanpa media audio visual.

Berdasarkan hasil analisis data diketahui bahwa layanan informasi dengan menggunakan media audio visual dapat meningkatkan sikap siswa terhadap kedisiplinan sekolah. Keefektifan ini terlihat dari jumlah keseluruhan skor kelompok eksperimen mengalami kenaikan signifikan dibandingkan kelompok kontrol yang kenaikannya tidak signifikan. Oleh karena itu, hendaknya guru BK atau konselor semakin kreatif dalam pelaksanaan bimbingan dan konseling khususnya dalam memberikan layanan informasi dengan menggunakan media.

Media yang digunakan dalam penyampaian informasi harus disesuaikan dan dilihat dari berbagai aspek. Penggunaan media yang digunakan dapat dipertimbangkan dari segi efektifitas dan efisiensinya. Senada dengan hal tersebut dalam pelaksanaan layanan informasi juga dapat dioptimalkan dan diaktifkan dengan menggunakan media tambahan dan metode (Tohirin, 2007:152).

Prayitno (2012:58) juga menjelaskan penggunaan media sebagai alat pendukung dalam pelaksanaan layanan informasi, seperti alat peraga, media tulis, media audio visual, grafis serta perangkat program elektronik (seperti rekaman, radio, televisi, komputer, OHP dan LCD). Sedangkan Kemp \& Dayton (dalam Azhar Arsyad, 2007:37) mengelompokkan media ke dalam beberapa jenis diantaranya: (1) media cetak, (2) media panjang, (3) overhead transparancies, (4) rekaman audiotape, (5) slide, (6) penyajian multiimage, (7) media audio visual atau rekaman video dan film hidup dan (8) komputer.

Media audio visual memiliki peran yang sangat penting dalam pemberian layanan informasi kepada siswa, dimana pemberian media audio visual efektif menumbuhkan perubahan yang signifikan sikap siswa, 
membawa kesegaran dan variasi bagi pengalaman belajar siswa, membuat hasil belajar lebih bermakna bagi berbagai kemampuan siswa, mendorong siswa lebih aktif dan terlibat dalam proses pembelajaran serta dapat melibatkan imajinasinya dan memberikan umpan balik yang diperlukan untuk membantu siswa menemukan seberapa banyak materi yang telah mereka pelajari (Dale, dalam Azhar Arsyad, 2007:23). Selain itu manfaat lainnya ialah lebih mudah dalam mengkondisikan kelas dengan cara menarik perhatian siswa, waktu yang dibutuhkan lebih efisien saat proses pembelajaran serta guru yang memberikan materi lebih mudah dalam menyampaikan materi kepada siswanya.

\section{KESIMPULAN}

Berdasarkan hasil penelitian, dapat disimpulkan secara umum bahwa layanan informasi dengan menggunakan media audio visual efektif meningkatkan sikap siswa terhadap kedisiplinan sekolah. Sedangkan secara khusus, yaitu: (1) terdapat perbedaan yang signifikan sikap siswa kelompok eksperimen terhadap kedisiplinan sekolah sebelum dan sesudah mengikuti layanan informasi dengan media audio visual, (2) terdapat perbedaan sikap siswa kelompok kontrol terhadap kedisiplinan sekolah sebelum dan sesudah mengikuti layanan informasi tanpa media audio visual. Perbedaan pada kelompok eksperimen lebih tinggi daripada kelompok kontrol. Oleh sebab itu, layanan informasi dengan media audio visual pada kelompok eksperimen efektif daripada layanan informasi tanpa media audio visual pada kelompok kontrol dan (3) terdapat perbedaan sikap siswa kelompok eksperimen yang diberikan layanan informasi dengan media audio visual dan kelompok kontrol yang diberikan layanan informasi tanpa media audio visual terhadap kedisiplinan sekolah.

Berdasarkan hasil penelitian dan pembahasan sebelumnya maka implikasi dari hasil penelitian ini dapat diajukan sebagai berikut.

1. Implikasi Teoretis

Hasil yang diperoleh melalui penelitian eksperimen ini dapat dijadikan sebagai bahan masukan bagi guru BK atau konselor sekolah dan personil sekolah lainnya dalam menyikapi rendahnya sikap siswa terhadap kedisiplinan sekolah, sehingga dapat memberikan pelayanan yang tepat untuk diberikan kepada siswa. Melalui layanan informasi dengan media audio visual yang mampu menjangkau jumlah siswa lebih banyak dalam mengembangkan berbagai potensi siswa secara optimal dan memecahkan berbagai permasalahan yang mereka alami.

2. Implikasi Praktis

Hendaknya pelaksanaan layanan informasi dengan media audio visual ini lebih diintensifkan dan diutamakan baik dalam bentuk orientasi dan sosialisasi maupun implementasi ke dalam bentuk program di sekolah. Oleh karena itu perlu peran serta yang aktif dari kepala sekolah, guru BK atau konselor sekolah, serta siswa. Adapun dalam pelaksanaan layanan informasi, hal-hal yang perlu dipersiapkan yaitu perencanaan kegiatan, pelaksanaan kegiatan, evaluasi kegiatan dan tindak lanjut. Temuan ini dapat menjadi masukan bagi semua pihak yang terlibat dalam proses pendidikan baik di sekolah maupun di luar sekolah (orangtua).

\section{SARAN}

Berdasarkan hasil-hasil penelitian, pembahasan dan kesimpulan yang telah dikemukakan, ada beberapa saran yang dapat diajukan sebagai tindak lanjut penelitian ini yaitu.

1. Bagi Guru BK atau Konselor

Guru BK atau konselor disarankan lebih melaksanakan layanan informasi dengan menggunakan media audio visual dalam meningkatkan sikap siswa terhadap kedisiplinan sekolah.

2. Bagi Kepala Sekolah

Kepala sekolah hendaknya menyediakan waktu khusus pada guru BK atau konselor masuk kelas 2 jam pembelajaran setiap minggunya, serta memfasilitasi guru BK atau konselor dengan media yang diperlukan dalam memberikan layanan kepada siswa antara lain media audio visual.

3. Bagi MGBK

Musyawarah Guru Bimbingan dan Konseling (MGBK) hendaknya mengadakan workshop terkait meningkatkan sikap siswa terhadap kedisiplinan sekolah melalui layanan informasi dengan menggunakan media audio visual. 
4. Bagi Jurusan Bimbingan dan Konseling

Sebagai bahan menghasilkan mahasiswa bimbingan dan konseling yang profesional melaksanakan layanan informasi dengan menggunakan media audio visual dalam meningkatkan sikap siswa terhadap kedisiplinan sekolah.

5. Bagi LPMP

Lembaga Penjamin Mutu Pendidikan (LPMP) dapat menjadikan hasil penelitian ini sebagai bahan dalam penataran yang diadakannya.

\section{DAFTAR RUJUKAN}

Agus Irianto. 2010. Statistik: Konsep dasar dan aplikasinya. Jakarta: Predana Media.

Azhar Arsyad. 2007. Media Pembelajaran. Jakarta: Raja Grafindo Persada.

Dewa Ketut Sukardi. 2003. Pengantar Pelaksanaan Program Bimbingan dan Konseling di Sekolah. Jakarta: Rineka Cipta.

Durkheim, E. 1970. Pendidikan Moral: Suatu studi teori dan aplikasi sosiologi pendidikan. Terjemahan oleh Lukas Ginting. 1990. Jakarta: Erlangga.

Kohut, S.Jr., \& Range, D.G. 2013. Discipline to Discipleship: A new part for school discipline. Christian Educators Journal, (Online). Vol. 1, No. II, (http://www.cejonline.com/articledc/discipline-to-discipleshipa-new-path-for-school-discipline/, diakses 24 Maret 2015).

Krech, D., Crutchfield, R.S., \& Ballachey, E.L. 1962. Individual in Society: A text of social psychology. New York: McGraw Hillbook.

Novasari Mardiana. 2014. "Pengaruh Penggunaan Teknik Ice Breaking dalam Bimbingan Klasikal terhadap Penguasaan Materi Bimbingan Sosial pada Siswa Kelas X IPA SMAN 2 Kota Bengkulu”. Jurnal Ilmiah Pendidikan, 2 (2): 9-12.

Prayitno. 2012. Jenis Layanan dan Kegiatan Pendukung Konseling. Padang: FIP UNP.

Soekidjo Notoadmojo. 1993. Ilmu Perilaku Kesehatan. Yogyakarta: PT Andi Offset.

Taylor, S.E., Peplau, L.A., \& Sears, D.O. Tanpa tahun. Psikologi Sosial. Terjemahan oleh Tri Wibowo. 2012. Jakarta: Kencana.

Tohirin. 2007. Bimbingan dan Konseling di Sekolah dan Madrasah (Berbasis Integrasi). Jakarta: Raja Grafindo Persada. 